\title{
The endogenous anti-angiogenic VEGF isoform, VEGF165 inhibits human tumour growth in mice
}

\author{
ES Rennel', E Waine', H Guan², Y Schüler', W Leenders³, J Woolard', M Sugiono', D Gillatt ${ }^{4}$, ES Kleinerman², \\ DO Bates ${ }^{*, 1}$ and SJ Harper'
}

'Microvascular Research Laboratories, Department of Physiology and Pharmacology, School of Veterinary Science, University of Bristol, Southwell Street, Bristol BS2 8EJ, UK; ${ }^{2}$ Division of Pediatrics Research, Unit 87, University of Texas MD Anderson Cancer Center, 15 I 5 Holcombe Blvd., Houston, TX, USA; ${ }^{3}$ Radboud University Nijmegen Medical Centre, Department of Pathology, Nijmegen, The Netherlands; ${ }^{4}$ Bristol Urological Institute, Southmead Hospital, Westbury-on-Trym, Bristol, UK

Vascular endothelial growth factor-A is widely regarded as the principal stimulator of angiogenesis required for tumour growth. VEGF is generated as multiple isoforms of two families, the pro-angiogenic family generated by proximal splice site selection in the terminal exon, termed $V E G F_{x x x}$, and the anti-angiogenic family formed by distal splice site selection in the terminal exon, termed $V E G F_{x x x} b$, where $x x x$ is the amino acid number. The most studied isoforms, VEGF 165 and $V E G F_{165} b$ have been shown to be present in tumour and normal tissues respectively. VEGF 165 b has been shown to inhibit VEGF- and hypoxia-induced angiogenesis, and VEGF-induced cell migration and proliferation in vitro. Here we show that overexpression of $V_{E G F}{ }_{165} b$ by tumour cells inhibits the growth of prostate carcinoma, Ewing's sarcoma and renal cell carcinoma in xenografted mouse tumour models. Moreover, VEGF $165 \mathrm{~b}$ overexpression inhibited tumour cell-mediated migration and proliferation of endothelial cells. These data show that overexpression of VEGF ${ }_{165} \mathrm{~b}$ can inhibit growth of multiple tumour types in vivo indicating that VEGF 165 b has potential as an anti-angiogenic, antitumour strategy in a number of different tumour types, either by control of $V E F_{165} b$ expression by regulation of splicing, overexpression of $V_{E G F_{165}}$, or therapeutic delivery of $V_{E G F_{165}}$ b to tumours.

British Journal of Cancer (2008) 98, 1250- 1257. doi:I0.1038/sj.bjc.6604309 www.bjcancer.com

Published online 18 March 2008

(c) 2008 Cancer Research UK

Keywords: VEGF; angiogenesis; anti-angiogenesis; splice variant; cancer growth; in vivo tumour inhibition

Vascular endothelial growth factor (VEGF-A) is the principal angiogenic promoter in most, if not all, cancers acting primarily on endothelial cells through its cognate receptors VEGF-R1 and VEGF-R2. VEGF is upregulated by hypoxia (Shweiki et al, 1992), and by overexpression of oncogenes such as mutant ras (Rak et al, 1995) and c-myc (Mezquita et al, 2005) in tumours, and stimulates the migration of endothelial cells, sprouting of blood vessels, and generation of new vessels from existing vasculature in tumours (reviewed in Ferrara, 2004). The resulting sustained blood flow, oxygen supply and waste removal enables more rapid growth of the tumour. Anti-VEGF therapy is now an additional therapeutic strategy to surgery, chemotherapy and radiotherapy, and recent trials of antibodies to VEGF as adjuvant therapy have shown significant clinical benefit in colorectal cancer (Hurwitz et al, 2004), renal carcinoma, non small cell lung, ovarian and other cancers.

Vascular endothelial growth factor is generated as multiple isoforms by alternative splicing of mRNA from 8 exons (Houck

*Correspondence: Dr DO Bates, Microvascular Research Laboratories, Department of Physiology and Pharmacology, School of Veterinary Science, University of Bristol, Southwell Street, Bristol BS2 8EJ, UK; E-mail: Dave.Bates@bris.ac.uk

Revised 31 January 2008; accepted 20 February 2008; published online 18 March 2008 et al, 1991). Conventional VEGF isoforms are pro-angiogenic, propermeability vasodilators. These isoforms contain exons $1-5$ and $8 \mathrm{a}$, with a variable contribution from exons $6 \mathrm{a}, 6 \mathrm{~b}, 7 \mathrm{a}$, and $7 \mathrm{~b}$, resulting in a family of peptides identified numerically by their amino-acid content, each with different heparin-binding properties (Houck et al, 1991). These are generically identified as VEGF $_{\mathrm{xxx}}$, where $\mathrm{xxx}$ refers to the number of amino acids. In 2002 (Bates et al, 2002) and 2004 (Woolard et al, 2004) we identified a sister family of isoforms of identical lengths and exon structure apart from the C-terminal exon in which distal splicing results in an alternate open-reading frame of six amino acids (exon 8b rather than 8a, SLTRKD vs CDKPRR) - generically referred to as VEGF $_{x x x}$ b (e.g. VEGF $_{165} \mathrm{~b}$, VEGF $_{121} \mathrm{~b}$ (Perrin et al, 2005), VEGF ${ }_{189} \mathrm{~b}$ (Miller-Kasprzak and Jagodzinski, 2008)). These isoforms are antiangiogenic and downregulated in renal tumours and metastatic melanoma (Bates et al, 2002; Pritchard-Jones et al, 2007). This antiangiogenic activity, generated by receptor binding but only weak receptor activation (Cebe Suarez et al, 2006) and inhibition of downstream VEGF-R2 signalling, has led to the hypothesis that VEGF $_{165} \mathrm{~b}$, or manipulation of C-terminal VEGF splicing to enhance more distal splicing, may be useful therapeutic tools in cancer.

We have previously shown that $\operatorname{VEGF}_{165} \mathrm{~b}$ is present in a range of normal tissues (Bates et al, 2002; Woolard et al, 2004) and there is a downregulation of the antiangiogenic $\mathrm{VEGF}_{165} \mathrm{~b}$ protein in 
malignant prostate cancer (Woolard et al, 2004) and metastatic melanoma (Pritchard-Jones et al, 2007) and mRNA in renal carcinoma (Bates et al, 2002). We also showed that $\mathrm{VEGF}_{165}$ expressing tumours grew faster than $\mathrm{VEGF}_{165} \mathrm{~b}$ expressing tumours, suggesting that $\mathrm{VEGF}_{165} \mathrm{~b}$ was not angiogenic. Moreover, we showed that tumours in which $\mathrm{VEGF}_{165} \mathrm{~b}$ expressing cells were mixed with VEGF $_{165}$ expressing cells grew more slowly than cells only expressing VEGF $_{165}$ (but more quickly than cells expressing VEGF $_{165} \mathrm{~b}$ alone). This latter finding rules out a possibility that $\mathrm{VEGF}_{165} \mathrm{~b}$ could be angiogenic in the presence of $\mathrm{VEGF}_{165}$. However, neither that, nor any other study, has shown whether $\mathrm{VEGF}_{165} \mathrm{~b}$ can inhibit tumour growth, whether it can inhibit VEGF $_{165}$-mediated tumour growth, or whether it can do so by inhibiting angiogenesis.

In this study, we have examined the effect of $\mathrm{VEGF}_{165} \mathrm{~b}$ overexpression on tumour growth, and $\mathrm{VEGF}_{165}$-mediated angiogenesis of prostate and renal cell carcinoma and on growth of Ewing's sarcoma cell and metastatic melanoma in xenografted mouse models.

\section{MATERIALS AND METHODS}

\section{Human tissue and RT - PCR of human TURP chips}

Frozen prostate chips were obtained from patients undergoing transurethral resection of the prostate (TURP) for lower urinary tract symptoms with benign prostatic hyperplasia and advanced prostate cancer (stage T3 Nx M0-1; UICC2002). The use of tissue was approved by the NBHST Ethical Committee.

Fifty to $100 \mathrm{mg}$ of 26 TURP tissue (nine malignant, 17 benign prostatic hypertrophy) was homogenised in Trizol reagent (Life Technologies Inc., Rockville, MD, USA) and mRNA was extracted by using the method of (Chomczynski and Sacchi, 1987). Eight microliters of RNA were treated with RNase free DNase (Promega, Madison, WI, USA) according to the manufacturer's guidelines to prevent genomic DNA contamination and mRNA was reverse transcribed using Moloney murine leukaemia virus reverse transcriptase and poly-d(T). cDNA was then amplified using intron spanning primers that detect $\mathrm{VEGF}_{165} \mathrm{~b}$ only, even in the presence of 1000 fold greater concentration of VEGF $_{165}$ mRNA (Bates et al, 2002). The cDNA was amplified using $1 \mu \mathrm{M}$ intronspanning primers designed to detect $\mathrm{VEGF}_{\mathrm{xxx}} \mathrm{b}$ (Bates et al, 2002) (Exon 4, 5'-GAGATGAGCTTCCTACAGCAC-3' and (Exon8b/7, 5'-TT AAGCTTTCAGTCTTTCCTGGTGAGAGATCTGCA-3') or VEGF $_{\mathrm{xxx}}$ with exon 8a (5'-CACCGCCTCGGCTTGTCACAT- $\left.3^{\prime}\right)$, together with $1.2 \mathrm{mM} \mathrm{MgCl}_{2}, 200 \mu \mathrm{M}$ dNTPs, and 1 unit of Taq DNA polymerase (Abgene), cycled 35 times, at $94^{\circ} \mathrm{C}$ for $30 \mathrm{~s}, 63^{\circ} \mathrm{C}$ for $30 \mathrm{~s}$ and $72^{\circ} \mathrm{C}$ for $60 \mathrm{~s}$. $\beta 2$-microglobulin was used as control amplification $(\beta 2$ forward primer $5^{\prime}$-GCATCATGGAGGTTTGAAGATG- $3^{\prime}, \beta 2$ reverse $5^{\prime}$-TAAGTTGCCAGCCCTCCTAGAG- $3^{\prime}$ ) at $55^{\circ} \mathrm{C}$ annealing temperature leading to a $220 \mathrm{bp}$ product. Full-length $\mathrm{VEGF}_{165} \mathrm{~b}$ or VEGF $_{165}$ in pcDNA3 vector were used as positive and negative controls. PCR products were run on 3\% agarose gels. PCR bands were excised and extracted using Qiaex (Qiagen, Crawley, UK), cloned using a TOPO TA Cloning ${ }^{\circledR}$ Kit (Invitrogen, Paisley, UK) and confirmed by sequencing.

\section{Establishment of overexpressing tumour cells}

All media and supplements were from Gibco/Invitrogen if not otherwise stated. PC3 cells were kindly donated by Professor J Masters from UCH, University of London. Ewing's sarcoma cell line, TC71, renal cell carcinoma cell line, CAKI, prostate cell line, PC3, and melanoma cell line, Mel57, were grown in Eagle's modified essential medium supplemented with $10 \%$ fetal calf serum (FCS), $2 \mathrm{~mm}$ L-glutamine, $1 \mathrm{~mm}$ sodium pyruvate, $1 \%$ non-essential amino acids, NEAA, $2 \%$ minimum essential medium vitamin solution, minimum essential media (Sigma Aldrich, Dorset, UK) supplemented with 10\% FCS, 1\% L-glutamine, $1 \%$ penicillin/streptomycin, 1\% NEAA or McCoy's 5A medium supplemented with $10 \%$ FCS and Ham F-12 supplemented with $10 \% \mathrm{FCS}, 1 \%$ penicillin/streptomycin, $1.5 \mathrm{gl}^{-1}$ sodium bicarbonate (Sigma Aldrich), respectively.

For transfection, 90\% confluent cells in 6-well plates were transfected with $0.5 \mu \mathrm{g}$ of plasmid DNA (pcDNA empty vector, pcDNA-VEGF 165, pcDNA-VEGF ${ }_{165}$ b or equal amounts of VEGF 165 and $\mathrm{VEGF}_{165} \mathrm{~b}$ plasmids) using Lipofectamine 2000 (Invitrogen, Paisley, UK) according to manufacturers protocols and Optimem media. Cells were selected with $375 \mu \mathrm{g} \mathrm{ml}^{-1}$ of geneticin and maintained at $125 \mu \mathrm{g} \mathrm{ml}^{-1}$. Transfected cells were analysed by an in-house developed $\mathrm{VEGF}_{165} \mathrm{~b}$-specific enzyme-linked immunosorbent assay (ELISA) (Perrin et al, 2005) or a commercial panVEGF ELISA (Duoset, R\&D Systems), that detects all isoforms of VEGF-A, to validate expression levels in selected cells. ELISA was performed either according to manufacturers instructions or as previously described (Woolard et al, 2004). Conditioned media from 200000 cells was collected and was analysed by ELISA after $48 \mathrm{~h}$ incubation. Mel57 cells were transfected with plasmid pIRESneo containing the $\mathrm{VEGF}_{165}$ or $\mathrm{VEGF}_{165} \mathrm{~b}$ cDNA essentially as described before (Kusters et al, 2007).

\section{Migration of cells with conditioned media}

Cultured supernatants from TC71, empty vector transfected TC71 or TC71/VEGF ${ }_{165} \mathrm{~b}$ cells were collected. Transwells (Costar, Cambridge, MA, USA) were pretreated with serum-free medium at $37^{\circ} \mathrm{C}$ for $1 \mathrm{~h}$ before seeding with human dermal microvascular endothelial cells, (HMVECs)at $1 \times 10^{5}$ per well in $100 \mu \mathrm{l}$ endothelial basal media (Cambrex, Baltimore, MD, USA) with $0.1 \%$ fetal bovine serum. These cells are commercially available cells generated from human foreskin tissue. The transwells were then inserted into 24-well plates containing $600 \mu \mathrm{l}$ of conditioned medium and incubated at $37^{\circ} \mathrm{C}$ for $6 \mathrm{~h}$ to allow HMVEC cells to migrate. Cells on the upper side of the filter were removed with cotton swabs. Migrated cells on the lower side of the filter were fixed and stained with haematoxylin and eosin. The number of migrated cells was counted under a binocular microscope.

\section{$\left[{ }^{3} \mathrm{H}\right]-$ thymidine incorporation of cells with conditioned media}

Human dermal microvascular endothelial cells $\left(3 \times 10^{3}\right)$ were seeded into 96-well cell culture plates and allowed to adhere for $5 \mathrm{~h}$ before the addition of conditioned medium from TC71 cells, empty vector transfected TC71 cells or TC71/VEGF ${ }_{165} \mathrm{~b}$ cells. Triplicate wells were used for each group. The cultures were labelled with $0.2 \mu \mathrm{Ci}$ per well of $\left[{ }^{3} \mathrm{H}\right]$ thymidine (ICN Biomedicals Inc., Radiochemicals Division, Irvine, CA, USA) during the last $24 \mathrm{~h}$ of a $48 \mathrm{~h}$ incubation. At the end of incubation, the cells were washed two times with HBSS, and $0.1 \mathrm{ml}$ of $0.1 \mathrm{~N} \mathrm{KOH}$ was added to lyse the adherent cells. The radioactive incorporation was determined using a plate harvester (Brandal Biomedical Research and Development Lab Inc., Gaithersburg, MD, USA) and Beta Plate Counter (Wallac 1450 Micro beta Counter, Perkin Elmer Life Sciences, Turku, Finland).

\section{In vitro growth analysis of cells}

For direct counting and proliferation of transfected CAKI cells, 30000 cells per 24 well were seeded out in triplicates. Cells were maintained in media supplemented with $0.01 \%$ or $10 \%$ FCS and were counted after 24 or $48 \mathrm{~h}$. The doubling time for each cell population was calculated using Prism software. The metabolic rate was analysed by seeding 5000 cells per 96 well in media 
supplemented with $0.01 \%$ FCS. After 24 or 48 h $50 \mu$ l of metabolic reagent was added (CellTiter $96^{\mathbb{R}}$ Aqueous One solution, Promega, Madison, WI, USA). Cells were incubated for $4 \mathrm{~h}$ at $37^{\circ} \mathrm{C}$ and analysed at $490 \mathrm{~nm}$.

\section{Animal housing and xenograft model}

One million Ewing sarcoma or Mel57, 8 million CAKI, 3 million PC3 overexpressing cells were injected subcutaneously into the back of unanaesthetised nude mice in $100 \mu \mathrm{l}$ sterile PBS. Xenotransplanted tumours were measured by calliper and tumour volume was calculated according to (length $\times$ width $\times$ (length + width)/2). Mice were culled by cervical dislocation when tumours reached $16 \mathrm{~mm}$ in any direction and organs and tumours were removed and snap-frozen or fixed in $4 \%$ PFA followed by paraffin embedding and $5 \mu \mathrm{m}$ sections were generated and stained with CD31/PECAM. Slides were boiled for $10 \mathrm{~min}$ in $0.01 \mathrm{M}$ sodium citrate boiling, followed by blocking in $5 \%$ goat serum for $1 \mathrm{~h}$, overnight incubation with $2.5 \mu \mathrm{g} \mathrm{ml}^{-1}$ anti-mouse PECAM antibody (Pierce Endogen) and for $1 \mathrm{~h}$ in $5 \mu \mathrm{g} \mathrm{ml}^{-1}$ ALEXA Fluor 488 goat anti hamster IgG (Invitrogen, Molecular Probes). Vessels were counted in six different fields at $\times 20$ magnification and verified at $\times 40$ magnification. Nude mice were kept under appropriate specific pathogen-free housing facilities according to government guidelines and procedures were carried out according to national guidelines and regulations.

\section{Statistical analysis}

Statistical analysis was performed using Prism. All data are given as mean \pm s.e.m. if not otherwise stated. Number of benign TUR and malignant chips expressing $\operatorname{VEGF}_{165} \mathrm{~b}$ was compared using Fisher's exact test. For tumour growth one-way analysis of variance (ANOVA) followed by Newman-Keuls' post hoc test (prostate) or two-way ANOVA followed by Bonferroni post hoc test (renal carcinoma) were used as data allowed. Weight, blood score, proliferation, cell doubling and metabolic rate were analysed by one-way ANOVA followed by Newman-Keuls' multiple comparison post hoc test. $P<0.05$ was considered significant.

\section{RESULTS}

VEGF $_{165} \mathrm{~b}$ is downregulated in malignant prostate tumours compared to benign prostate tissue and reduced tumour growth in xenograft model

RNA was extracted from human prostate chips from patients undergoing TURP and expression of $\mathrm{VEGF}_{165}$ and $\mathrm{VEGF}_{165} \mathrm{~b}$ mRNA was analysed by isoform specific PCR. Expression of $\mathrm{VEGF}_{165} \mathrm{~b}$ was found in 10 out of 11 benign samples and $\mathrm{VEGF}_{165}$ was also present in 10 out of 11 (see Figure 1A). In malignant prostate on the other hand, $\mathrm{VEGF}_{165} \mathrm{~b}$ was only found in four out of nine, whereas the $\mathrm{VEGF}_{165}$ expression was found in eight out of nine (see Figure 1B).

Human prostate cancer cells, PC3 cells, were transfected with control, $\mathrm{VEGF}_{165} \mathrm{~b}, \mathrm{VEGF}_{165}$ expression plasmids, or a combination of the two and injected into nude mice. The tumour volume was monitored over time and at day 18 the tumour volumes were significantly different $(P<0.05)$. Figure $1 \mathrm{C}-\mathrm{F}$ illustrates representative images of each group. The pro-angiogenic $\mathrm{VEGF}_{165}$ transfected cells produced rapidly growing tumours although not statistically different from control tumours $(P>0.5)$. Conversely the VEGF $_{165} \mathrm{~b}$ transfectants resulted in smaller tumours $(P<0.05$ at 22 days compared with pcDNA3 controls), and those expressing both isoforms were significantly smaller than those expressing $\operatorname{VEGF}_{165}$ only $(P<0.05$ at 18 days $)$.
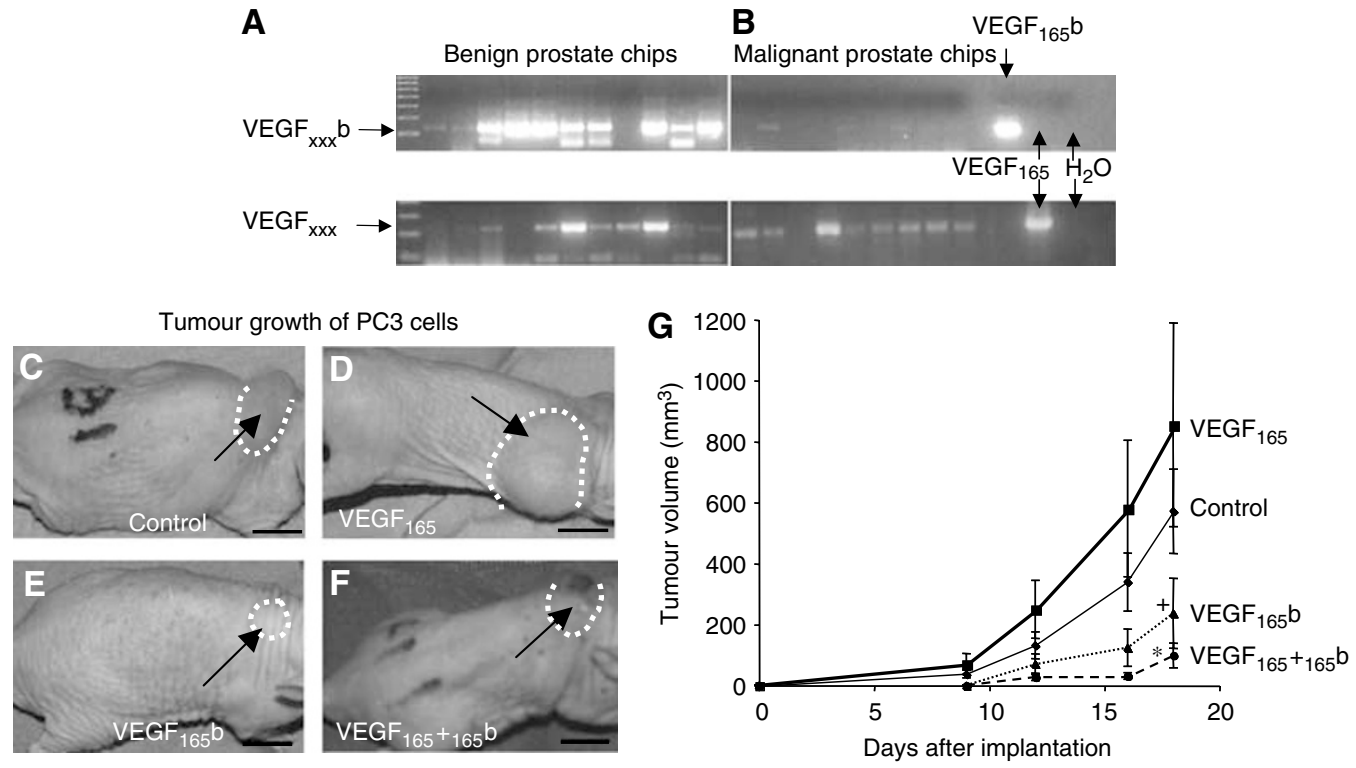

Figure I The antiangiogenic VEGF $165 \mathrm{~b}$ is downregulated in human malignant prostate tumour and reduces prostate tumour growth. Anonymous examples of $V E G F_{x x x}$ and $V E G F_{x x x} b$ mRNA expression in TURP chips from benign prostate hypertrophy $(\mathbf{A})$ and malignant prostate cancer $(\mathbf{B})$. (A) RTPCR of mRNA extracted from benign prostate chips using primers to detect VEGF $F_{x x x} b$ and VEGF $F_{x x x}$. Ten out of I I benign samples showed expression of

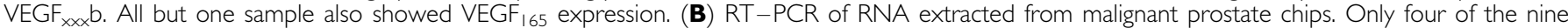

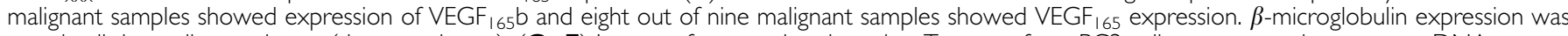
seen in all the malignant tissues (data not shown). (C-F) Images of tumour-bearing mice. Tumours from PC3 cells overexpressing empty pcDNA ${ }_{3}$ vector

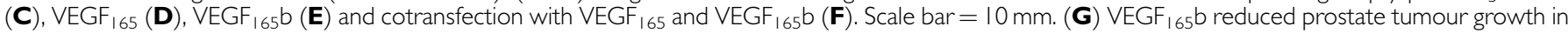
a xenograft mouse model. Three million PC3 cells were injected and VEGF 165 b overexpression reduced control and VEGF 165 -mediated tumour growth at day $18\left(P<0.05\right.$ Kruskal-Wallis, *control vs VEGF $165 \mathrm{~b} P<0.05,{ }^{+} \mathrm{VEGF}_{165}$ Vs VEGF $\left.165 \mathrm{~b} P<0.05\right)$. 
Table I VEGF expression in transfected CAKI cells

\begin{tabular}{|c|c|c|}
\hline Transfection & $\operatorname{VEGF}_{165} \mathbf{b}\left(\mathrm{pg} \mathrm{ml}^{-1}\right)$ & Total VEGF $\left(\mathrm{pg} \mathrm{ml}^{-1}\right)$ \\
\hline pcDNA & - & 906 \\
\hline VEGF $_{165}$ & - & 1020 \\
\hline$V E_{G F}{ }_{165} b$ & 1562 & 1797 \\
\hline $\operatorname{VEGF}_{165}+{ }_{165} b$ & 975 & 1424 \\
\hline
\end{tabular}

ELISA performed on conditioned media after $48 \mathrm{~h}$ from 200000 transfected and selected CAKI cells.
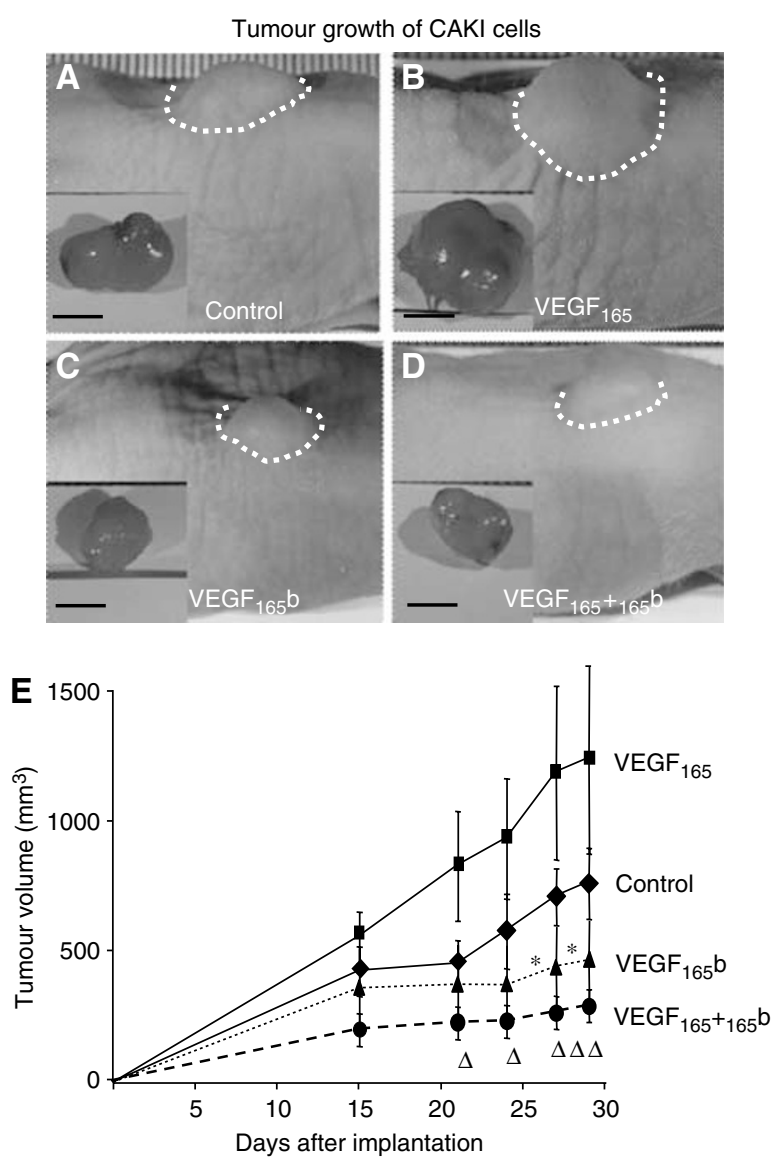

$\mathbf{F}$
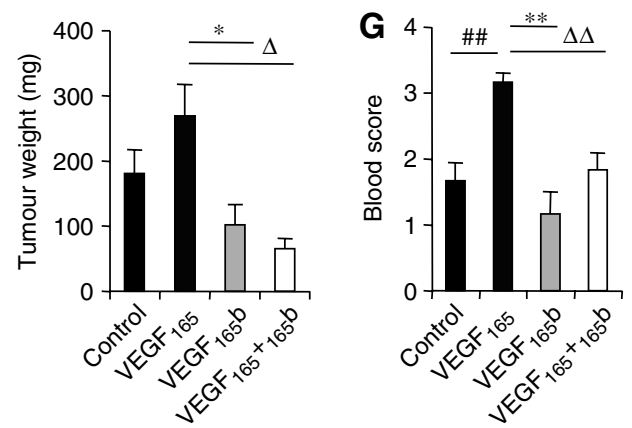

Figure $2 V E F_{165} b$ inhibits tumour growth in renal cell carcinomas. Renal cell carcinoma $\left(8 \times 10^{6}\right.$ CAKI) cells, transfected with $p C^{2} D A_{3}$ vectors expressing empty vector $(\mathbf{A}) \mathrm{VEGF}_{165}$ (B), $\mathrm{VEGF}_{165} \mathrm{~b}(\mathbf{C})$ or cotransfected with VEGF 165 and $V E F_{165} b$ (D) were injected into the back of nude mice, $n=6$ mice per group, photographs taken at 29 days. Tumour border outlined by dotted line. Inset shows excised tumours. (E) Tumour growth curves. (F) Tumour weight at day of culling. (G) Macroscopic estimation of blood content at day of culling. (*P $<0.05 V E G F_{165} b$ vs

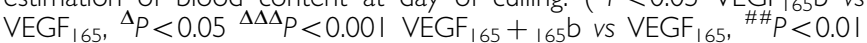
$V \mathrm{EGF}_{165}$ vs PcDNA)

\section{VEGF $_{165} \mathrm{~b}$ overexpression reduces renal cell carcinoma growth}

Renal carcinoma (CAKI) cells, transfected with the different VEGF isoforms were analysed for VEGF expression. VEGF $_{165} \mathrm{~b}$ was undetectable in empty vector and $\mathrm{VEGF}_{165}$-transfected cells and VEGF $_{165} \mathrm{~b}$ expression was readily detectable in the $\mathrm{VEGF}_{165} \mathrm{~b}$ - or cotransfected cells (Table 1). The endogenous levels of VEGF 165 were high in CAKI cells and transfection of VEGF $_{165}$ increased the total levels (Table 1).

Eight million transfected CAKI cells were injected into nude mice and monitored over time. Injection of control transfected cells resulted in solid, bloody tumours after 29 days (see Figure 2A), and $\mathrm{VEGF}_{165}$-expressing tumours resulted in larger, bloody tumours after 29 days (see Figure 2B), VEGF $_{165}$ bexpressing tumours, while they did grow (see Figure 2C) were smaller, and less bloody. Cells expressing both isoforms also resulted in small, relatively blood-free tumours that were not different from the VEGF $_{165}$ b-expressing tumours (see Figure 2D). Figure 2E shows that $\mathrm{VEGF}_{165} \mathrm{~b}$-expressing tumours grew significantly slower than $\mathrm{VEGF}_{165}$-expressing tumours (overall $P<0.001$, VEGF $_{165} v s$ VEGF $_{165} \mathrm{~b} P<0.05$ at day $27, \mathrm{VEGF}_{165} v s$ both $P<0.05$ day 24 and $P<0.001$ day 27). No significant difference was found between tumours formed from cells expressing $\mathrm{VEGF}_{165}$ and control or between those expressing VEGF $_{165} \mathrm{~b}$ and both VEGF isoforms.

Upon excision of the tumours, they were weighed and scored blindly for blood content. $\mathrm{VEGF}_{165}$-expressing tumours were significantly larger (see Figure $2 \mathrm{~F}$ ) than control and $\mathrm{VEGF}_{165} \mathrm{~b}$ expressing tumours, which also resulted in a significant reduction of tumour volume $\left(P<0.05 \mathrm{VEGF}_{165} v s\right.$ both isoforms or $\left.\mathrm{VEGF}_{165} \mathrm{~b}\right)$. There was a non-significant reduction in tumour volume for $\mathrm{VEGF}_{165} \mathrm{~b}$-expressing tumours compared with control transfected. Macroscopically the tumours differed with more blood in $\mathrm{VEGF}_{165}$-expressing tumours compared to any other of the groups $\left(P<0.01\right.$ VEGF $_{165}$ vs either of the other groups, Figure $\left.2 \mathrm{G}\right)$. Similar data was observed with a smaller initial tumour cell injection $\left(2 \times 10^{6}\right.$ cells, data not shown).

The growth rates of the transfected CAKI cells were analysed. There was no difference in the proliferation as measured by direct counting of cells (see Figure 3A and B) or analysis of metabolic rate (see Figure $3 \mathrm{C}$ ). Both experiments were performed in the presence of serum with the same results (data not shown).

These results indicate that $\mathrm{VEGF}_{165} \mathrm{~b}$ overexpression reduced tumour growth in renal cell carcinoma cells grown in mice even in the presence of $V_{E G F}{ }_{165}$. The tumour inhibition by $\mathrm{VEGF}_{165} \mathrm{~b}$ appears not to be through reduction in tumour cell proliferation.

\section{$\mathrm{VEGF}_{165} \mathrm{~b}$ overexpression reduced Ewing's sarcoma growth and tumour-conditioned media reduced endothelial cell proliferation and migration}

Injection of TC71 Ewing's sarcoma cells overexpressing $\mathrm{VEGF}_{165} \mathrm{~b}$ subcutaneously into the back of nude mice resulted in tumours that grew significantly slower than control cells over a time period of 29 days (see Figure $4 \mathrm{~A}$ ). To determine whether $\mathrm{VEGF}_{165} \mathrm{~b}$ secreted from the tumour cells was active on the cells that go on to form blood vessels, conditioned media from the Ewing's sarcoma cells, TC71 cells, overexpressing VEGF $_{165} \mathrm{~b}$ was used to study migration of human microvascular vein endothelial cells, HMVEC. Fetal calf serum resulted in migration of HMVEC as expected (see Figure 4B), and conditioned media from control-transfected tumour cells induced a similar level of migration of HMVEC (see Figure $4 \mathrm{C}$ ). VEGF $_{165} \mathrm{~b}$ overexpressing tumour cells resulted in less migration compared to tumour-conditioned media or controlstimulated cells (see Figure 4D).

To determine whether $\mathrm{VEGF}_{165} \mathrm{~b}$ could inhibit growth of endothelial cells, DNA synthesis in HMVEC was measured. 

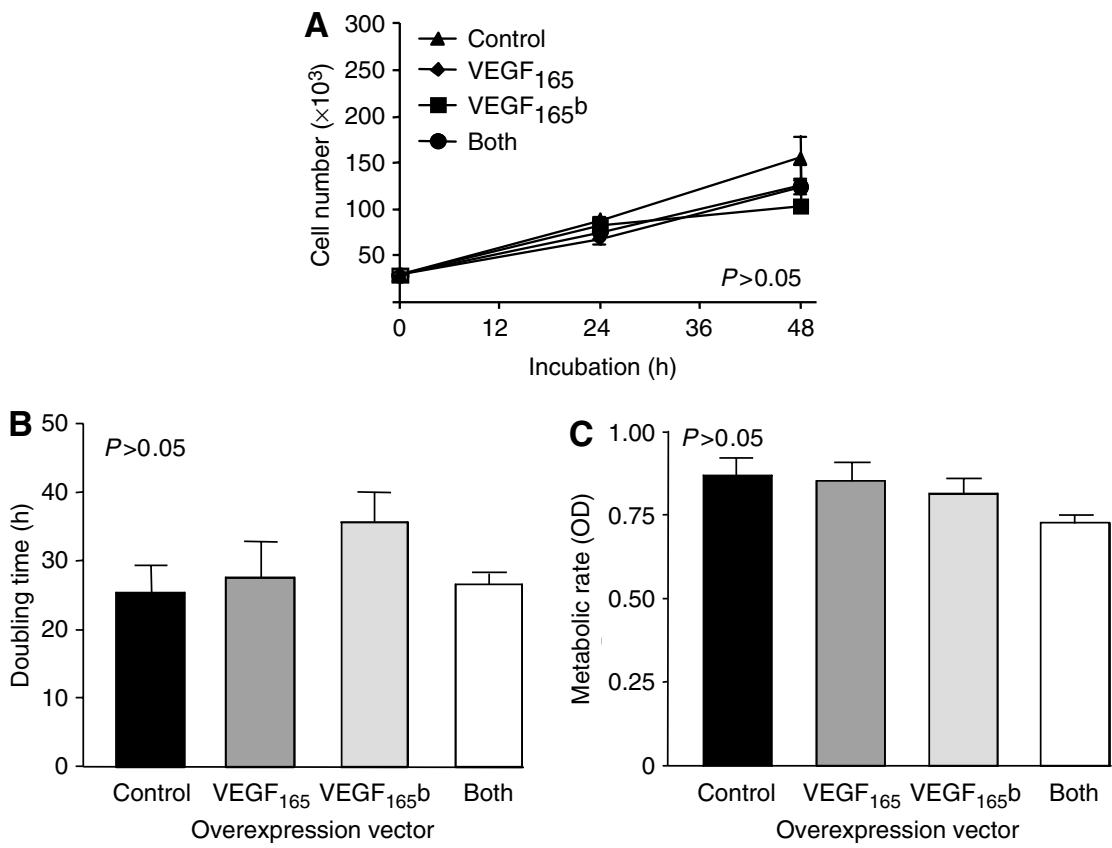

Figure 3 Overexpression of VEGF ${ }_{165}$ b does not affect proliferation when overexpressed in renal cell carcinoma cells in vitro. (A, B) Transfected renal cell carcinoma CAKI cell growth was analysed by direct counting of cells after 24 and $48 \mathrm{~h}$ in low serum (0.0 \% FCS). The doubling time was calculated for each cell population. No significant differences were observed in either instance $(P>0.05 n=3$, one-way ANOVA). (C) Cell viability and metabolic rate was analysed at $48 \mathrm{~h}$ in low serum with transfected CAKI cells. No significant difference was observed $(P>0.05 n=4$, one-way ANOVA).
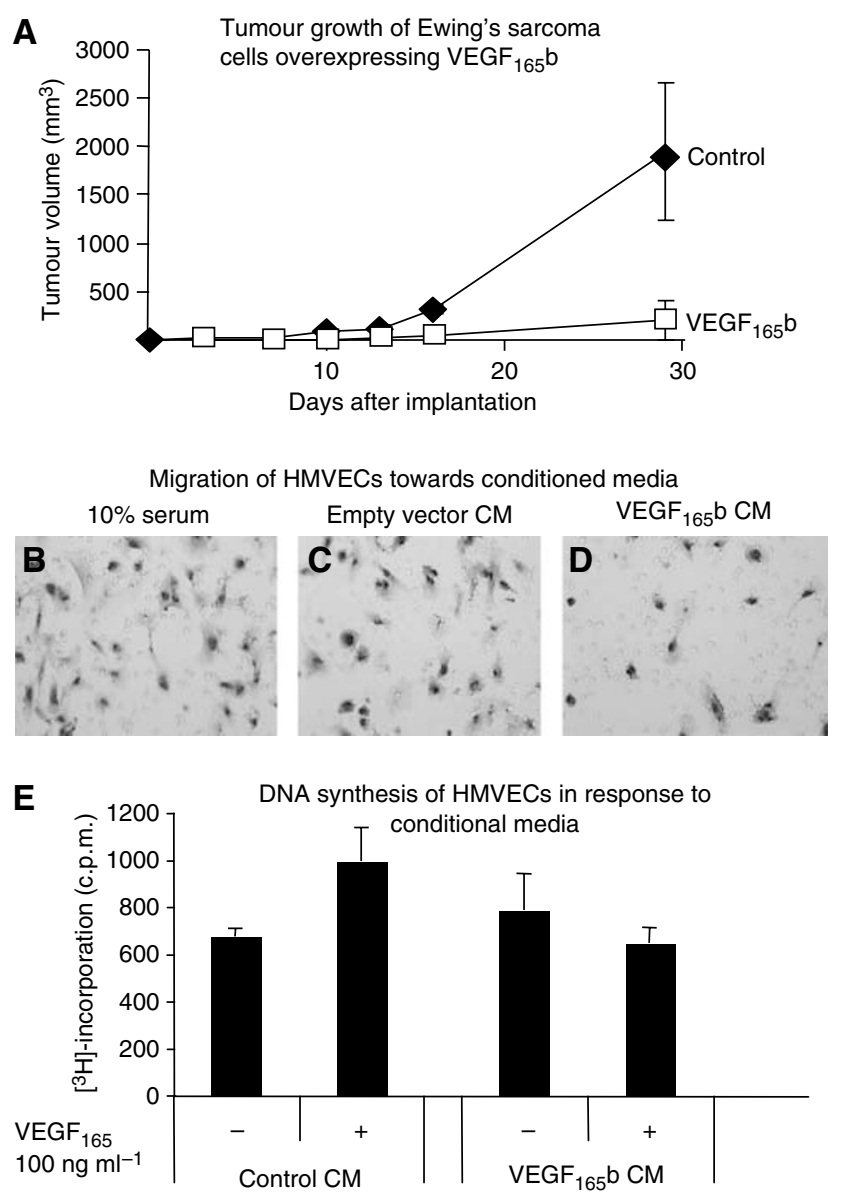

VEGF $_{165}$ increased $\left[{ }^{3} \mathrm{H}\right]$-incorporation into HMVECs when added to control tumour cell-conditioned medium. $\mathrm{VEGF}_{165} \mathrm{~b}$-conditioned media did not increase DNA synthesis of HMVEC cells and reduced $\mathrm{VEGF}_{165}$-mediated DNA synthesis (see Figure 4E). However, $\mathrm{VEGF}_{165} \mathrm{~b}$ did not reduce proliferation below the level of control-conditioned media, indicating that the inhibition of proliferation was specific for $\mathrm{VEGF}_{165}$-mediated proliferation.

\section{Rate of tumour growth depends upon the VEGF isoform expression}

The results above suggest that switching expression of VEGF from $\mathrm{VEGF}_{165}$ to $\mathrm{VEGF}_{165} \mathrm{~b}$ might result in reduced tumour growth rates. To determine whether this was the case a VEGF-deficient melanoma cell line (Mel57), which normally grows slowly by cooption of existing vasculature (Westphal et al, 2000) was transfected with $\mathrm{VEGF}_{165}$ or $\mathrm{VEGF}_{165} \mathrm{~b}$, and implanted subcutaneously. Figure 5 shows that whereas $\mathrm{VEGF}_{165}$-expressing tumours rapidly grew, $\mathrm{VEGF}_{165} \mathrm{~b}$ expressing-tumours were very slow growing, matching that of the previously published co-option dependent parental cell line, indicating that switching expression

Figure $4 V V G_{165} b$ transfection reduces migration, proliferation and tumour growth in vivo of Ewing's sarcoma tumours. (A) VEGF ${ }_{165}$ b overexpression in Ewing's sarcoma cells resulted in significantly smaller tumours 30 days after implantation of $1 \times 10^{6}$ cells, $P<0.05$ after 7 days, one way ANOVA. (B) Human microvascular endothelial cells, HMVECs (stained with haematoxylin), migrated towards 10\% serum and to conditioned media from Ewing's sarcoma cells $(\mathbf{C})$. In contrast VEGF 165 b overexpression by these cells reduced migration compared to conditioned media and 10\% serum (D). (E) When HMVECs were incubated in conditioned media from tumour cells VEGF ${ }_{165}\left(100 \mathrm{ng} \mathrm{ml}^{-1}\right)$ could still stimulate increased proliferation. Conditioned media from cells overexpressing $V_{E G F}{ }_{165} b$ inhibited this increase. 


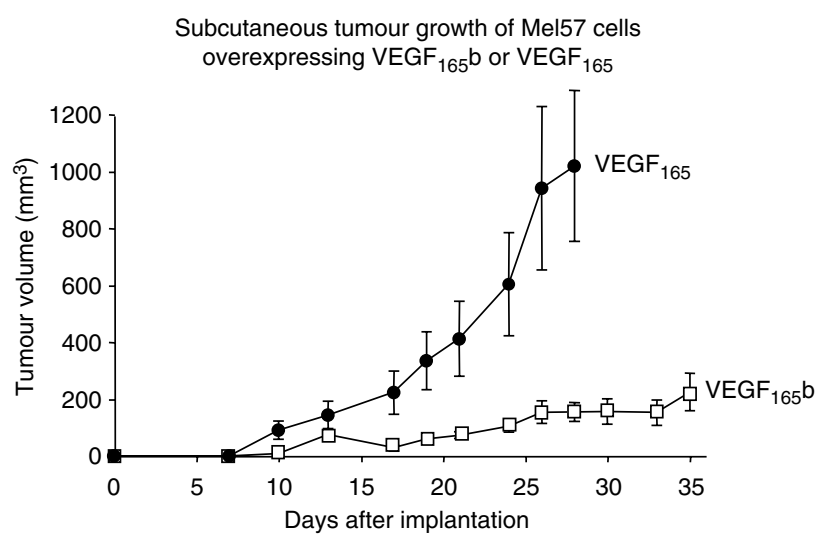

Figure 5 Switching expression from $V E G F_{165}$ to $V E_{165} b$ inhibits tumour growth. Mel57 melanoma cells, which express very low levels of VEGF in vivo were transfected with VEGF 165 or VEGF ${ }_{165} b$ and $1 \times 10^{6}$ cells injected subcutaneously into nude mice. Whereas the VEGF 165 transfected cells grew rapidly, VEGF ${ }_{165} \mathrm{~b}$ transfected cells grew no more quickly than previous studies have shown for this VEGF-deficient cell type. from VEGF $_{165}$ to $\mathrm{VEGF}_{165} \mathrm{~b}$ by altering splicing may be a useful therapeutic strategy.

\section{VEGF $_{165}$ b inhibits VEGF $_{165}$-mediated tumour vessel in- growth}

To examine the mechanism for the reduction of tumour growth in vivo and the proposed anti-angiogenic effect of $\mathrm{VEGF}_{165} \mathrm{~b}$, tumour vessels were visualised by PECAM staining of excised tumour sections. In the CAKI tumours there was a significant increase in microvascular density from $7.03 \pm 0.86$ per high power field in control (Figure $6 \mathrm{~A}$ ) to $8.37 \pm 1.06$ in $\mathrm{VEGF}_{165}$-expressing tumours (Figure 6B). In contrast, there was a significant reduction in MVD to $2.17 \pm 0.65 / \mathrm{hpf}$ in $\mathrm{VEGF}_{165} \mathrm{~b}$-expressing tumours $(P<0.01$ compared with control Figure $6 \mathrm{C})$, indicating that $\mathrm{VEGF}_{165} \mathrm{~b}$ inhibited vessel growth in CAKI tumours. This was also significantly lower than $\operatorname{VEGF}_{165}(P<0.001)$. Furthermore, tumours in which $\mathrm{VEGF}_{165} \mathrm{~b}$ and $\mathrm{VEGF}_{165}$ were coexpressed also had significantly reduced MVD $(2.98 \pm 0.56$, Figure $6 \mathrm{D}, P<0.001$ compared with $\mathrm{VEGF}_{165}$ ), indicating that $\mathrm{VEGF}_{165} \mathrm{~b}$ inhibited $\mathrm{VEGF}_{165}$-mediated blood vessel growth (Figure $6 \mathrm{E}$ ). Similar results
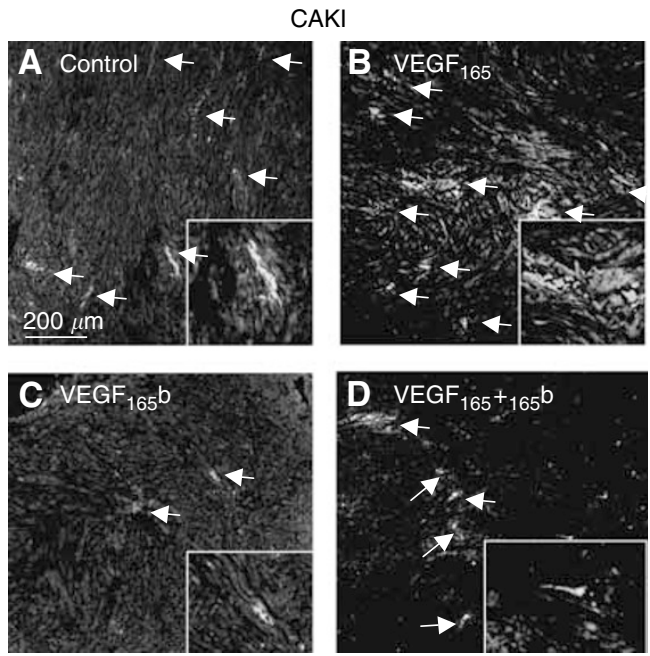

PC3
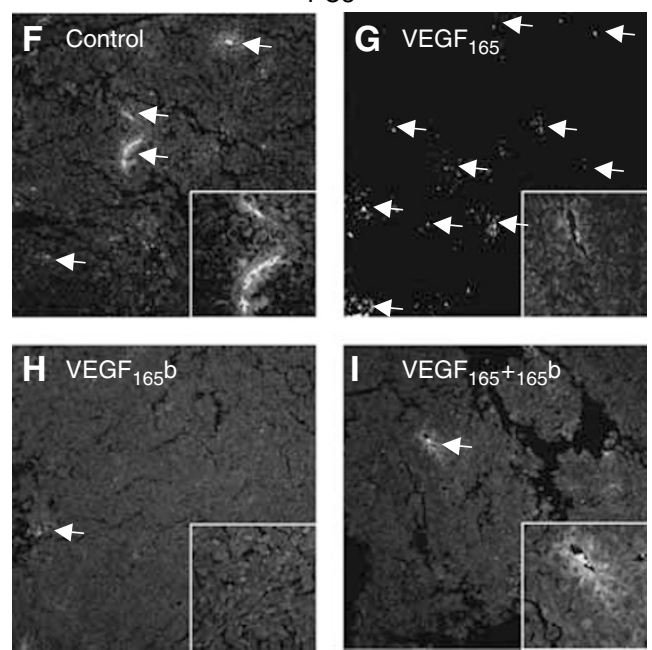
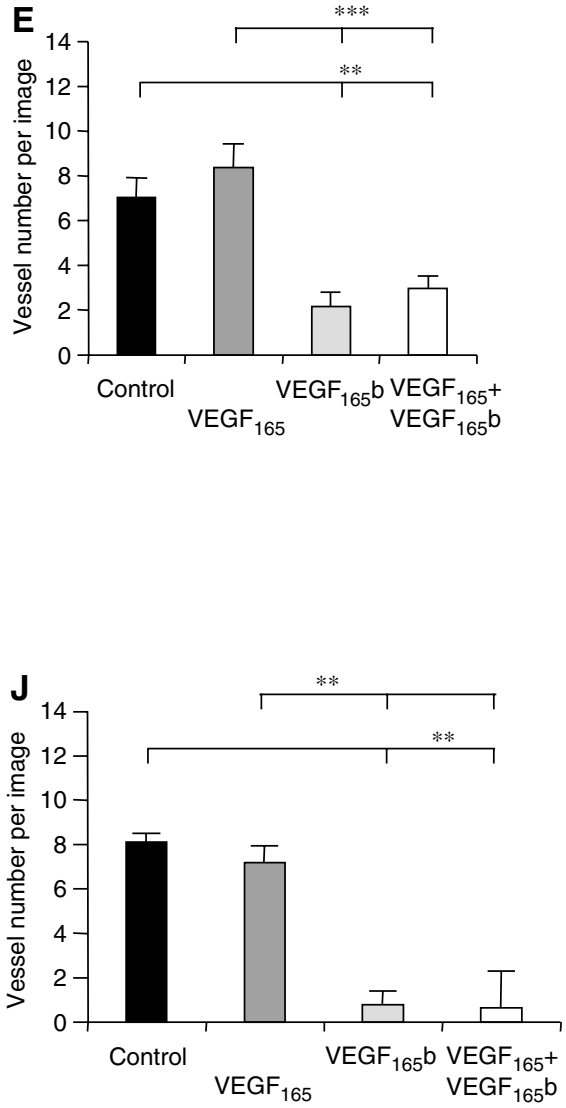

Figure 6 VEGF 165 b reduces vessel density in tumours. Tumour sections were stained with PECAM antibody to visualise vessels. $(\mathbf{A}-\mathbf{D}$ and $\mathbf{F}-\mathbf{I})$ Representative images at $\times 10$ magnification and $\times 20$ (image inset). Quantification of vessel number in CAKI tumours $(\mathbf{E})$ and $P C 3(\mathbf{J})$. Overall $P<0.0001$ One-way ANOVA $P<0.0001 * * P<0.01$, **** $P<0.00$ I compared to control or VEGF 165 . 
were seen in PC3 cells (Control 8.13 $\pm 0.40, V_{E G F} 1657.17 \pm 1.66$, $\mathrm{VEGF}_{165} \mathrm{~b} 0.78 \pm 0.78, \mathrm{VEGF}_{165}+\mathrm{VEGF}_{165} \mathrm{~b} 0.64 \pm 0.64$. see Figure $6 \mathrm{~F}-\mathrm{J})$.

\section{DISCUSSION}

VEGF has been generally considered in over 20000 papers since 1990 as a pro-angiogenic tumour-enhancing endothelial-specific growth factor (Ferrara, 2002) and successful antiangiogenic agents have been directed at VEGF in cancer and eye disease (Gragoudas et al, 2004; Hurwitz et al, 2004). In 2002, we identified for the first time that an alternative splice site in the terminal exon 8 of the VEGF mRNA could be used to generate an alternative isoform (Bates et al, 2002), $\mathrm{VEGF}_{165} \mathrm{~b}$, which we subsequently showed to be one of a family of VEGF isoforms generated by C-terminal distal splice site selection, the $\mathrm{VEGF}_{\mathrm{xxx}} \mathrm{b}$ family of isoforms (Perrin et al, 2005). However, while the conventional exon $8 \mathrm{a}$ containing isoforms predominate in the pathological angiogenic phenotype seen in tumours, proliferative retinopathy, arthritis etc (Ferrara, 2002), the exon $8 \mathrm{~b}$ containing isoforms, which are anti-angiogenic in vivo are downregulated in a number of pathologies (Bates et al, 2002; Woolard et al, 2004; Cebe Suarez et al, 2006; Schumacher et al, 2007). Loss of the C-terminal domain (resulting in $\mathrm{VEGF}_{159}$ ) results in a loss of angiogenic activity of the VEGF molecule, but does not result in inhibition of angiogenesis (Cebe Suarez et al, 2006). The mechanism of action through which $V_{E G F} F_{x x x} b$ prevents tumour growth is not yet fully elucidated. However, it is clear from previous studies that VEGF $_{165} \mathrm{~b}$ is able to bind both VEGFR-1 (Cebe Suarez et al, 2006) and VEGFR-2 (Woolard et al, 2004), but initiates only weak signalling of the receptor to induce tyrosine phosphorylation (Woolard et al, 2004; Cebe Suarez et al, 2006), and is unable to induce a behavioural change in large vessel endothelial cells that mimic that shown by microvascular endothelial cells in vivo during angiogenesis (Woolard et al, 2004; Cebe Suarez et al, 2006). This study indicates for the first time that $\mathrm{VEGF}_{165} \mathrm{~b}$ can exert its action by preventing tumour secreted endothelial growth factors (presumably $\mathrm{VEGF}_{165}$, or other $\mathrm{VEGF}_{\mathrm{xxx}}$ isoforms) from acting on microvascular endothelial cells.

Several studies have shown that VEGF expression in the malignant tissue and/or plasma correlates with aggressive disease (reviewed in Delongchamps et al, 2006) and VEGF mRNA and protein are upregulated in prostate carcinoma (Ferrer et al, 1997; Jackson et al, 1997). Our data indicate that there is a switch in VEGF expression allowing the pro-angiogenic $\mathrm{VEGF}_{\mathrm{xxx}}$ isoforms to dominate within malignant prostate and renal cell carcinoma, allowing the tumours to develop their own blood supply.

The current findings indicate that $\mathrm{VEGF}_{165} \mathrm{~b}$ may have a therapeutic role in cancer treatment, by altering splicing of the VEGF gene to result in over-expression of $\mathrm{VEGF}_{165} \mathrm{~b}$ at the expense of $\mathrm{VEGF}_{165}$. The latter mechanisms (control of splicing at the C-terminal end of the VEGF gene), is therefore one of intense interest, but unfortunately almost nothing has been published concerning the regulation of splicing of the VEGF gene. The vascular phenotype in both pathological and physiological angiogenesis may therefore depend on the balance of VEGF isoforms. We have speculated then that in addition to malignant change related to cell turnover/survival (which may also be determined by splicing (Venables, 2004) a second event occurs in which splicing control of many factors with pre- and antiangiogenic splice variants occur to allow the malignant disease to progress (Ladomery et al, 2006).

To conclude, these findings indicate that $\operatorname{VEGF}_{165} \mathrm{~b}$ is able to inhibit growth of at least three different tumour types, and that the mechanism of inhibition is through inhibiting angiogenesis rather than a direct effect on tumour cell growth.

\section{ACKNOWLEDGEMENTS}

We thank Leslie Sage for technical assistance. This work was supported by a Cancer Research UK Development Grant (A5047), the British Heart Foundation Grants (BB2000003 and BS06/005), National Kidney Research Fund Grant (R15/2/2003), the Prostate Research Campaign, Prostate Cancer Research Foundation, and the North Bristol Specific Cancer Projects Fund. The Ewing's Sarcoma experiments were carried out by Hui Guan and Eugenie Kleinerman at MD Anderson Cancer Center, Texas. The Mel57 experiments were carried out by William Leenders at the Radboud University, Nijmegen, The Netherlands.

\section{REFERENCES}

Bates DO, Cui TG, Doughty JM, Winkler M, Sugiono M, Shields JD, Peat D, Gillatt D, Harper SJ (2002) VEGF165b, an inhibitory splice variant of vascular endothelial growth factor, is downregulated in renal cell carcinoma. Cancer Res 62: 4123-4131

Cebe Suarez S, Pieren M, Cariolato L, Arn S, Hoffmann U, Bogucki A, Manlius C, Wood J, Ballmer-Hofer K (2006) A VEGF-A splice variant defective for heparan sulfate and neuropilin-1 binding shows attenuated signaling through VEGFR-2. Cell Mol Life Sci 63: 2067-2077

Chomczynski P, Sacchi N (1987) Single-step method of RNA isolation by acid guanidinium thiocyanate-phenol-chloroform extraction. Anal Biochem 162: $156-159$

Delongchamps NB, Peyromaure M, Dinh-Xuan AT (2006) Role of vascular endothelial growth factor in prostate cancer. Urology 68: 244-248

Ferrara N (2002) Role of vascular endothelial growth factor in physiologic and pathologic angiogenesis: therapeutic implications. Semin Oncol 29: $10-14$

Ferrara N (2004) Vascular endothelial growth factor: basic science and clinical progress. Endocr Rev 25: 581-611

Ferrer FA, Miller LJ, Andrawis RI, Kurtzman SH, Albertsen PC, Laudone VP, Kreutzer DL (1997) Vascular endothelial growth factor (VEGF) expression in human prostate cancer: in situ and in vitro expression of VEGF by human prostate cancer cells. J Urol 157: 2329-2333

Gragoudas ES, Adamis AP, Cunningham Jr ET, Feinsod M, Guyer DR (2004) Pegaptanib for neovascular age-related macular degeneration. N Engl J Med 351: 2805-2816
Houck KA, Ferrara N, Winer J, Cachianes G, Li B, Leung DW (1991) The vascular endothelial growth factor family: identification of a fourth molecular species and characterization of alternative splicing of RNA. Mol Endocrinol 5: 1806-1814

Hurwitz H, Fehrenbacher L, Novotny W, Cartwright T, Hainsworth J, Heim W, Berlin J, Baron A, Griffing S, Holmgren E, Ferrara N, Fyfe G, Rogers B, Ross R, Kabbinavar F (2004) Bevacizumab plus irinotecan, fluorouracil, and leucovorin for metastatic colorectal cancer. $N$ Engl $J$ Med 350: 2335-2342

Jackson MW, Bentel JM, Tilley WD (1997) Vascular endothelial growth factor (VEGF) expression in prostate cancer and benign prostatic hyperplasia. J Urol 157: 2323-2328

Kusters B, Kats G, Roodink I, Verrijp K, Wesseling P, Ruiter DJ, de Waal RM, Leenders WP (2007) Micronodular transformation as a novel mechanism of VEGF-A-induced metastasis. Oncogene 26: 5808-5815

Ladomery MR, Harper SJ, Bates DO (2006) Alternative splicing in angiogenesis: the vascular endothelial growth factor paradigm. Cancer Lett 249(2): $133-142$

Mezquita P, Parghi SS, Brandvold KA, Ruddell A (2005) Myc regulates VEGF production in B cells by stimulating initiation of VEGF mRNA translation. Oncogene 24: 889-901

Miller-Kasprzak E, Jagodzinski PP (2008) 5-Aza-2-deoxycytidine increases the expression of anti-angiogenic vascular endothelial growth factor $189 \mathrm{~b}$ variant in human lung microvascular endothelial cells. Biomed Pharmacother 62 (in press) 
Perrin RM, Konopatskaya O, Qiu Y, Harper S, Bates DO, Churchill AJ (2005) Diabetic retinopathy is associated with a switch in splicing from anti- to pro-angiogenic isoforms of vascular endothelial growth factor. Diabetologia 48: 2422-2427

Pritchard-Jones RO, Dunn DB, Qiu Y, Varey AH, Orlando A, Rigby H, Harper SJ, Bates DO (2007) Expression of VEGF(xxx)b, the inhibitory isoforms of VEGF, in malignant melanoma. $\mathrm{Br} J$ Cancer 97(2): $223-230$

Rak J, Mitsuhashi Y, Bayko L, Filmus J, Shirasawa S, Sasazuki T, Kerbel RS (1995) Mutant ras oncogenes upregulate VEGF/VPF expression: implications for induction and inhibition of tumor angiogenesis. Cancer Res 55: $4575-4580$

Schumacher VA, Jeruschke S, Eitner F, Becker JU, Pitschke G, Ince Y, Miner JH, Leuschner I, Engers R, Everding AS, Bulla M, Royer-Pokora B (2007) Impaired glomerular maturation and lack of VEGF165b in Denys-Drash syndrome. J Am Soc Nephrol 18: 719-729
Shweiki D, Itin A, Soffer D, Keshet E (1992) Vascular endothelial growth factor induced by hypoxia may mediate hypoxia-initiated angiogenesis. Nature 359: $843-845$

Venables JP (2004) Aberrant and alternative splicing in cancer. Cancer Res 64: $7647-7654$

Westphal JR, Van't Hullenaar R, Peek R, Willems RW, Crickard K, Crickard U, Askaa J, Clemmensen I, Ruiter DJ, De Waal RM (2000) Angiogenic balance in human melanoma: expression of VEGF, bFGF, IL-8, PDGF and angiostatin in relation to vascular density of xenografts in vivo. Int I Cancer 86: $768-776$

Woolard J, Wang WY, Bevan HS, Qiu Y, Morbidelli L, Pritchard-Jones RO, Cui TG, Sugiono M, Waine E, Perrin R, Foster R, Digby-Bell J, Shields JD, Whittles CE, Mushens RE, Gillatt DA, Ziche M, Harper SJ, Bates DO (2004) VEGF165b, an inhibitory vascular endothelial growth factor splice variant: mechanism of action, in vivo effect on angiogenesis and endogenous protein expression. Cancer Res 64: 7822-7835 